\title{
SOSYAL KELAM BAĞLAMINDA YOKSULLUK VE YOKLUKTA BİR SIĞINAK OLARAK DININ HAYATA YANSIMALARI*
}

Saadet Altay $^{* *}$

Öz

Sosyal kelam açısından, dini inanç ve düşüncenin özellikle yoksul veya yoksun bırakılmış, dezavantajlı gurup olarak toplumdaki kadının, yaşadığı bütün olumsuzluklara karşı gösterdiği tepki, geliştirdiği argüman, ya da hangi sığınakları kendisi için bir korunak alanı oluşturduğunun belirlenmesi adına 2006-2016 yılları arasında Diyarbakır'ın en yoksul kesimleri olarak değerlendirilen dört mahallesinde (Ben u Sen Mahallesi, Fatih Paşa Mahallesi, Hasırlı Mahallesi ve Fiskaya Mahallesi) yapılmış bir saha çalışması etrafında yürütülen araştırmaya dayanır. 35 kadın ile 2 yıl boyunca "katılımcı gözlem" ve "derinlikli görüşme" yollarıyla elde edilen sonuçlar 1şığında yoksulluk ve bu yoksulluğun meşrulaştırıcı ve dayanılır kılıcı unsuru olan dini söylem arasındaki ilişkiyi değerlendirmeye çalıştım. Bu ilişki genel olarak dini söylemin günlük yaşamlarını sürdürme noktasında yüklendiği işlevin ortaya konmasıdır. Nitekim yoksulluğun kök saldığı bu mahallelerde diğer cins olarak kabul edilen şiddet, kan davası, yoksunluk, terk edilmek vb. şekilde sıralayabileceğimiz durumlara maruz kalan kadınların, bu yaşadıklarını hangi dini söylemin meşrulaştırdığını ortaya koymaktır. Yaptığım bu saha çalışması neticesinde, dinin özellikle yoksul kadınların yaşamında nasıl bir hayat tutamağı olarak yer aldığının izlerini sürmeye ve bunu Sosyal Kelam disiplini açısından değerlendirmeye çalıştım.

Anahtar kelimeler; Kadın, Yoksulluk, Toplumsal Cinsiyet, Din, Sosyal Kelam

\section{REFLECTIONS OF RELIGION ON LIVE AS DEPRIVED AND POVERTY IN THE CONTEXT OF SOCIAL THEOLOGY}

\begin{abstract}
Within the realm of social theology, religious beliefs and thoughts among the poor or deprived and the disadvantaged group of women in the society, reacted to all the negativities they experienced, the argument they developed, or to determine which shelters constitute a shelter for them between 2006-2016. It is based on a research carried out in a field study conducted in four of Diyarbakir's poorest neighborhoods (Ben u Sen district, Fatih Pasha district, Hasırlı district and Fiskaya district). Through "participatory observation" and "in-depth interviews" with 35 women for 2 years, we
\end{abstract}

\footnotetext{
* Bu makale 2017 tarihinde Prof. Dr. Ahmet Erkol danışmanlığında tamamlanan "Sosyal Kelam Açısından Yoksul Kadınlarda Dini Düşünce ve Bu Düşüncenin Sosyal Yaşama Yansımaları (Diyarbakır Örneği) başlıklı doktora tezinden üretilmiştir.

Article Types / Makale Türü: Research Article / Araştırma Makalesi Received / Makale Geliş Tarihi: 21/10/2020, Accepted / Kabul Tarihi: 01/12/2020 DOI: https://doi.org/10.26791/sarkiat.814455

** Saadet Altay, Ağrı İbrahim Çeçen Üniversitesi, İslami ilimler Fakültesi, Temel İslam Bilimleri Bölümü, Kelam ve Mezhepler Tarihi Anabilim Dalı saltay@agri.edu.tr ORCID ID: https://orcid.org/000-0001-2345-678
} 
evaluated the relationship between poverty and religious discourse and how religion legitimates and tolerates poverty. This study reveals the function of religious discourse in maintaining the daily lives of women. It reveals how religious discourse legitimizes the women who are exposed to situations such as violence, blood feud, deprivation, abandonment etc. In this field study, I trace how religion takes place in the lives of especially poor women and evaluate this in terms of Social Theory.

Keywords: Women, Poverty, Gender, Religion, Social Theology

\section{GİRİs}

Bu makalenin dayandığı araştırmanın sosyal alanı Diyarbakır'ın yoksul mahalleleridir. Sokaklarının en dar ve evlerinin iç içe geçtiği mahalleleri olan Ben u Sen, Fatih Paşa, Hasırlı ve Fiskaya mahallesinde yaşayan yoksul kadınların dini düşünceleri ve sahip oldukları bu dini düşüncenin yoksulluklarını yaşamadaki etkisini kendi ruh dünyalarına ve sosyal yaşamlarına nasıl yansıdığını ortaya koymak önemlidir. Bu çerçevede yapılmış çalışmaların çoğu ya sosyoloji, ya da kültürel antropoloji açısından ele alınmıştır. Aynı sorunun sözü edilen bilimsel disiplinlerden yararlanmakla birlikte Sosyal Kelam açısından ele alınıyor olmasının ayrı bir önemi olduğunu vurgulamakta yarar vardır. Bir yönüyle de inancın yoksul kadınların yaşamı örnekliğinden hareketle Sosyal Kelamın saha araştırmalarında nasıl kullanılabileceğinin bir örnekliğini de teşkil etmiş olmaktadır.

Çalışma alanı olarak belirlediğim alanların nasıllığına bakıldığında; Şehrin en işlek caddelerine mesafeleri yüz metreyi bulmamalarına rağmen şehre aidiyetleri neredeyse yoktur. Bu mekânlar adeta şehrin öteki yüzüdür. Uyuşturucu, şiddet, namus cinayetleri ve yaşadıkları yoksullukla tanımlanabilecek mahallelerde yaşamanın ne kadar zor olabileceğini tahmin etmek bile oldukça güç iken, bir kadın olarak buralarda yaşamanın beraberinde getirdiklerini tahayyül etmek daha da güçleşmektedir. Bu anlamda makalenin genel seyri içerisinde bizzat kendilerine ait ifadeler, konuyu anlamaya yardımcı olacaktır.

Makalemizde kısmen görüleceği gibi kadınların yaşadıkları zorlukları anlattıkları bu sokaklar onların acılarına şahitlik etmektedir. Gidecek fazla mekânı olmayan, çoğu zaman sokak başında veya evlerinin önünde oturan bu kadınların dünyasına girmek, farklı hayatlarla tanışmak demektir.

Kendileriyle diyalog kurulduğunda, anlattıkları hayat hikayeleri, bu makalenin ana temasını oluşturmaktadır. Bu düşünceden hareketle konunun daha somut anlaşılmasını sağlamak adına makalede, sahada yaşayan kadınların konuşmaları, ya da değerlendirmelerine daha fazla yer verdim. Bilinçli bir tercih olarak yoksul kadınların kendi konuşmalarından hareketle konuyu temellendirdim. Hatice hanım ${ }^{1}$ :"Ben çox aci çektım, kocam beni çox dövidi, çocı̆̆ım esrar içi, çox fakirıx. Valla bazen yiyecax ekmek bulamiyıx. Ama işte ne yapax bu da bızım kaderımızdır. Buna da şükür.” Bu ifadeler makalenin konusunu ve çerçevesini oluşturacak düşünceleri barındırmakta, "acı", "şiddet", "çaresizlik" ve "yoksulluk"un getirdiği çaresizliğe karşı hangi sığınakların kullanılmış olduğunu göstermektedir. Burada kullanılan dini argümanalar ve her bir anlatımda dile getirilen dini terimlerin hayata yansıma biçimi ve zorluklara göğüs germede bunun gördüğü işlev konunun esasını oluşturmaktadır.

\footnotetext{
${ }^{1}$ Tezde kullanılan isimler şahısların gerçek isimleri değildir.
} 
Sosyal hayat, -ekonomi, eğitim, sağlık, güvenlik vb. konular açısından dezavantajlı olan bu mahallelerde genel olarak bu coğrafyada kadın olmanın zorlukları ile birlikte bu mahallede yaşayan yoksul ve her türlü şiddete maruz kalan kadınlarda daha da ağır bir şekilde kendisini göstermektedir. Hatice Hanımın, eşinden şiddet görmesi, çocuğu ile ilgili söyledikleri, kadın olmanın yanı sıra anne olmanın da problemlerini ortaya koyuyor. Yaşadıklarına rağmen cümlesini "Şükür" ve "kader" gibi dini terimlerle bitirmesi, Müslüman yoksul kadınların, hem inanç biçimlerinin ve hem de sosyal yaşamdaki davranışlarının hangi sonuçları beraberinde getirdiğini ortaya koymaya çalıştım. Sosyal Kelam açısından ele alınan bu konunun doğru anlaşılabilmesi için başta sosyoloji ve özellikle kültürel antropolojiden yararlandığımı tekrar ifade etmem gerekir.

$\mathrm{Bu}$ anlamda öncelikle kadınların yaşadıkları mekânın bir tasvirinin yapılması konunun anlaşılması noktasında bize kolaylık sağlayacaktır. Lefebvre“nin “ mekânın Üretimi”" adlı eserinde vurguladığı gibi; beden ve mekân arasındaki ilişkilerin durağan ya da sabit değil, bunun yerine sürekli değişen ve birbirini dönüştüren dinamik özelliğe vurgu yaptılar. Bedenleri mekânsız ve mekânları bedensiz düşünmemek bu dinamiğin temel noktasını oluşturuyor. Yani bedenler bir yandan kendilerini mekânlara kazıyıp yansitırken, aynı zamanda mekânlar tarafından da fiziksel, toplumsal, cinsel ve söylemsel olarak üretiliyorlar. "Mekân" dediğimiz şey belirli bedenlerin kurulmasında aktif bir görev üstlenerek, öznelerin bedenselliklerin üzerinde derin izler bırakıyor. Bu yüzden de farklı mekânların ve sosyokültürel çevrelerin belirli psikolojiler, duygusallıklar, somut davranış biçimleri ve inanışlar üzerinde nasıl derin izler bıraktığına bakmak son derece önemlidir. ${ }^{2}$

\section{Bir Yaşam Alanı Olarak Mahalleler ya da Mekânın Ürettiği Sosyal Yaşam Biçimi}

Diyarbakır'ın yoksul mahalleleri genellikle, Diyarbakır surlarının hemen dibinde kurulmuş kesimidir. Bir sınır çizgisi olarak da algılayabileceğimiz surlar, zengin ile fakir, eğitimli ile eğitimsiz, güzel bir yaşama hakkına sahip olanların! ve bu haktan mahrum olanların! suçlu! ile masumlar! arasında bir sınır çizgisi görevini görmektedir. Yerel ağızda "beden dibi" olarak tanımlanan mahalleler, bir zamanlar yazın güneşin girmesini engelleyip şehri serinleten, kışın da sıcaklık kaybını önleyen dar sokaklardan oluşur.

$\mathrm{Bu}$ mahalleler şehrin öteki yüzü gibidir. Şehrin diğer kısmında yaşayan insanlar tarafından pek görülmeyen, şehrin dezavantajlı durumlarını (yoksulluk, şiddet vs.) omuzlarında taşıyan kadınlar, çocuklar ve gençler adeta buralarda toplanmışlardır. Bu mahalleler kentsel sıkışmışlık içinde, sosyal haklarının birçoğuna erişimde yoksunluk yaşayan vatandaşların yaşam alanlarıdır. Önceleri şehrin en önemli yerleşim yeri olup hala "Eski Diyarbakır" olarak nitelenen bu mahalleler bir süre sonra şehrin dezavantajlı insanlarının toplandığı bir alan vazifesi görmeye başlamıştır.

Makaleye konu olan mahallelerin yerleşim biçimine ve meskenlerin genel durumuna baktığımızda, özellikle 1980'li yılların sonunda bölgede tırmanan gerilim ve şiddet olaylarının sonucunda, zorunlu veya isteyerek boşalan köylerden Diyarbakır'a yönelen göç, çarpık kentleşme sürecini hızlandırmıştır. Nüfus ve yapılaşma yoğunluğu kentlerde mevcut yığma yapıları yatay yüklere karşı dayanıksızlığı nedeniyle sorun teşkil etmektedir. 1970'den itibaren yoğun göçle birlikte gelişigüzel projesiz ve kuralsız

\footnotetext{
${ }^{2}$ Henri Lefebvre, Mekânın Üretimi, Trc. Işık Ergüden 3.Bs.(İstanbul; Sel yayınları, 2015), 134. ; İrvin Cemil Schick, Bedeni, Toplumu Kainatı Yaratmak, Trc. Pelin Tünaydın 1. Bs.(İstanbul; İletişim yayınlar1,2011), 183.
} 
olarak inşa edilen (çok katlı, tuğla duvarlı) yığma yapılar, Diyarbakır ilinde çevre düzenlemesi ve alt yapı yetersizliği gibi birçok problemi de beraberinde getirmiştir.

Araştırma kapsamında yer alan hanelerde ortalama hane halkı 6,67 kişidir. Türkiye ortalaması aynı dönemde bu oran 4.2 dir. Genel bir tanımlama ile Diyarbakır'da kişi başına düşen konut alanı 12,90 metrekare olup bu rakam 100 metrekare alana sahip bir konutta ortalama olarak 8 kişinin yaşadığını göstermektedir. 1990-1994 döneminde inşa edilen konut miktarı bakımından Türkiye ortalaması 40.6 birim iken Diyarbakır' da bu oran 29.26 birim olmuştur. Bu veriler göç eden nüfusun önemli bir kısmında, münferit konutlar yerine bir konutun birden fazla aile tarafından ortak kullanıldığ 1 bir yerleşme biçiminin baskın olduğunu göstermektedir. ${ }^{3}$

Bu sıkışma yüzünden, bu mahallelerde yaşayan insanların hem hane içinde hem de hane dışında kendilerine ait özel yaşam alanlarının olmayışı, güven duygusunu zedelemektedir. Kişisel alanın tehdit altında olduğu hissi beraberinde sıkışmışlık hissi uyandırır ve bu sıkışmışlık hissi çoğu zaman şiddet ile neticelenmektedir. ${ }^{4}$

Söz konusu bölgelerdeki ortak gelişme gettolaşma olarak da tanımlanan, kentler içinde yalıtılmış toplulukların zuhur etmesidir. Bu alanlar şiddet ve yoksulluk mekânlarıdır. Bu mekânlar, hırsızlık ve uyuşturucu vb. gibi yasa dışı hadiseler için birer alan haline gelir ve bu hadiseler bu mekânlarla sınırlı kalmayarak bir süre sonra şehrin geri kalan kısmına da bu suçları ihraç eder. $\mathrm{Bu}$ durum toplumun yardım etme duygusunu zedelemekte, empati kurma arzusunu yok etmekte ve güvenlik merkezli yaklaşımları güçlendirmektedir. Toplumun yoksulluğa desteğinin zayıflaması (büyük çoğunluğu masum olan) gençleri, kadınları, çocukları ve işsizleri derinden etkilemektedir. A. Ryan bunu "ilgilenmekten vazgeçme" olarak adlandırmaktadır. Yoksulluğun bu yeni durumla bağlantılı olarak kötü okul, kötü eğitim, suçla erken tanışma ve toplumun ve medyanın damgalamasıyla iyice daralan çember içinde yoksulluğu daha da artırmaktadır. Gençler iş bulamıyor, kadınlar yoksul bir hayat sürüyor, kocalar iş bulamadıkları için kahvehanelerde zamanını öldürerek geçiriyor. Bu durum sürdürdükleri hayatı kendileri açısından anlaşılabilir kılmak için bireyler tarafından ancak "değiştirilemeyen kader, talih" gibi kavramlarla açıklanmaya çalışılıyor. ${ }^{5}$

Makaleye konu olan kadınların yaşadıkları mekân hakkında vermiş olduğum bu bilgiler, bu kadınların yaşam tarzlarını anlama konusunda az da olsa ipucu mahiyetindedir. Şimdi ise konunun temelini teşkil eden unsurlardan bir diğeri olan toplumsal cinsiyet bağlamında bu kadınların bir portresini ortaya koymaya çalışacağım.

\section{Mekânın Biçimlendiği Kadın ve Sosyal Yaşama Yansımaları}

Mekânsal yetersizlik yüzünden çoğu zaman evlerinin önünde oturan kadınların yaşadıklarını konuşmalarına gerek kalmadan yüzlerinden okumak mümkündür. İlk çocukluk döneminden itibaren evlilik, annelik deneyimleri olmak üzere her dönemde yaşadıkları tecrübeler ve bu tecrübelerde o kadınların yoksulluk, şiddet vb. olumsuzlukları dini argümanlar ile nasıl yaşanılır kıldıklarını anlatmaya başlamadan önce bu kadınlardan bahsetmek istiyorum.

\footnotetext{
${ }^{3}$ Havva Özyılmaz, Sertaç Karakaş, Abdulhalim Karaşin, Diyarbakır'da Yoğun Göçün Getirdiği Çarpık Kentleşme Sorunları, TMMOB Afet Sempozyumu, Ankara; Mattek Matbaacılık, 2007), 329-330.

${ }^{4}$ Kemal Sayar, Olmak Cesareti, (İstanbul; Timaş yayınları, 2013), 82-83.

${ }^{5}$ Filiz Baloğlu, "Kentsel Yoksulluk: İstanbul'dan Küçük Bir Kesit," Sosyoloji Konferanslarl, 0/31(2005), 242-243.
} 
Kimsenin görmediği görmek istemediği bu kadınlar, toplum tarafından da görülmediğini söylemek çok aşırı bir yorum barındırmaz. Kız çocuğu olarak dünyaya gelmenin daha ilk saatlerinde ebeveynler tarafından buruklukla karşılanır ve toplumda çokça duyulan "kız çocuğu doğdu" sessizliği içinde başlayan yaşam Butler'ın deyimiyle "yaşanılır bir hayat" olma özelliğinden uzak olmanın ilk adımını atmışlardır. ${ }^{6}$ Bereketin

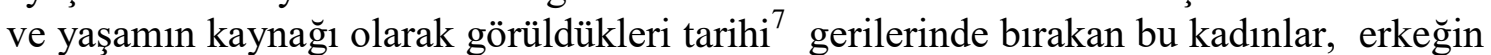
söylemleriyle baskınlanmış ya da yok sayılmak istenmiştir. ${ }^{8}$ Varlıkları ancak evlilikle, ${ }^{9}$ anne ve eş ${ }^{10}$ olmak yoluyla "bir anlam" ifade eder, Erkeklerin yazdığ 1 bir tarihte, ${ }^{11}$ bilimde ${ }^{12}$ ve doğada yaşamaya, ${ }^{13}$ çalışmış ve bunun mücadelesini vermiştir.

Yine Butler'ın deyimiyle 'Kırılgan Hayat'ları vardır. Onların hayatları sadece kendi adlarına kararlar verilerek tahrip edilip ölüm noktasına gelene kadar ihmal edilebilir bir hayattır. Bu, sadece hayatın son bulması değil aynı zamanda kırılgan olmasıdır. Kırılgan bir hayat içinde kişinin yaşantısı hep kendi tercihleri dışında, başkaları tarafından belirlenmekte; "kaderi başkalarının elinde" olmak demektir. Bazen babanın elinde, bazen kocanın, bazen şeyhinin, bazen evladının; çoğu zaman da toplumun, kültürün ve ataerkil dini söylemin kendisi hakkında verdiği kararları yaşamak zorunda kalmıştır. Hep 'biz' denmiştir ama bu biz hep tanınmayan bilinmeyen biri olarak kalmıştır. ${ }^{14}$

Sadece toplumun değil onların da kendilerine dair olumsuz düşüncelerin ağırlığını; belki de farkında olmadan, bütün bir ömrü "eksik!" olduklarını hissederek yaşarlar. Freud'un biyolojik bedene dayandırarak ifade ettiği kadının eksik olma hali neredeyse bütün hayatlarına sirayet etmiştir. Biyolojileri kaderleri haline getirilmiştir. $^{15}$ Toplumsallaştırmanın bütün unsurları onların "beden eksiklikleri ya da biyolojileri" üzerinde ittifak etmiş şekilde kadınları, erkeğin bir adım ötesine itmektedir. İdeolojik, ${ }^{16}$ biyolojik, ${ }^{17}$ toplumsal ${ }^{18}$ sinıfsal, ${ }^{19}$ ekonomik ve eğitsel, ${ }^{20}$ güç merkezli, ${ }^{21}$ ruhbilimsel,

\footnotetext{
${ }^{6}$ Judith Butler, Savaş Tertipleri, Trc. Şeyda Öztürk 1. Bs.(İstanbul; Yapı Kredi yayınları, 2009), 21-22.

${ }^{7}$ Merlin Stone, Tanrılar Kadınken, Trc. Nilgün Şarman, 1. Bs.(İstanbul; Payel yayınları, 2000), 43.; Bkz. Pervin Erbil, Kibele'den Pandora'ya Kadının Tarihsel Yenilgisi, 3. Bs.( Ankara; Arkadaş yayınları, 2012), 23-52.; Fatmagül Berktay, Tek Tanrılı Dinler Karşısında Kadın, 4. Bs. (İstanbul; Metis yayınları, 2012), 57-59.

${ }^{8}$ Luce İrigaray, Başlangıçta Kadın Vardı, Trc. İlknur Özallı-Melike Odabaş, 1. Bs.(İstanbul; Pinhan yayınları, 2014), 15.

9 Simone De Beauvour, Kadın Íkinci Cins Evlilik Çăğ, Trc. Bertan Onaran,8. Bs. (İstanbul; Payel yayınları, 2010), 12.

${ }_{10}$ De Beauvour, Kadın İkinci Cins, 112.

${ }^{11}$ Bkz. Fatmagül Berktay, Tarihin Cinsiyeti, 4. Bs.(İstanbul; Metis yayınları, 2012) 16-34.

12 Evelyn Fox Keller, Toplumsal Cinsiyet ve Bilim Üzerine Düşünceler, Trc. Ferit Burak Aydar 1. Bs.(İstanbul; Metis yayınlar1, 2007), 103-118.

${ }^{13}$ Val Plumwood, Feminizm ve Doğaya Hükmetmek, Trc. Başak Ertür, 1. Bs.(İstanbul; Metis yayınları), 2004,64.

${ }^{14}$ Butler, Savaş Tertipleri, 21.

15 Bkz. Sigmund Freud, Cinsiyet Üzerine,Trc. A.Avni Öneş, 18. Bs.(İstanbul; Say yayınları,2015); Zeynep Direk (der.), Cinsiyetli Olmak Sosyal Bilimlere Feminist Baklşlar, 4. Bs. (İstanbul; Yapı Kredi yayınlar1, 2014), 25-26.; Bkz. Maria Mies, Veronika Bennholdt- Thomsen, Cloudia Von Werlhof, Son Sömürge: Kadınlar, Trc. Yıldız Temurtürkan 2. Bs.(İstanbul; İletişim yayınları, 2014),103.; Bkz. Karen Horney, Kadının Ruhsal Yapısı, Trc. Nilgün Şarman 1. Bs.(İstanbul; Payel yayınları, 1998), 37-38.; Simone De Beauvoir, Kadın İkinci Cins Genç Kızlık Çă̆l, Trc. Bertan Onaran, 7. Bs.(İstanbul; Payel yayınları, 1993), 35.; Jacqueline Rose, Görme ve Cinsellik, Trc. Ayşe Deniz Temiz, 1.Bs. (İstanbul; Metis yayınları, 2009), 19.

16 Kate Millet, Cinsel Politika, Trc. Seçkin Selvi 3.Bs. (İstanbul; Payel yayınları, 2011), 48.; Louis Althusser, İdeoloji ve Devletin İdeolojik Aygıtlarl, Trc. Alp Tümertekin 2. Bs.(İstanbul; İthaki yayınları, 2014),53.

${ }^{17}$ Millet, Cinsel Politika, 50.

${ }^{18}$ Millet, Cinsel Politika, 60.
} 
${ }^{22}$ mitik ve dinsel bütün yorumlar, ${ }^{23}$ onun ikinci cins olması üzerine kuruludur. Bedenin kaderin alanı olmayacağına dair itiraz seslerinin çıkmaya başlayıp tartışmaların yoğunlaştı̆̆ bir zamana rağmen bu böyle olmaya devam etmektedir. ${ }^{24}$

Kadınların bu yaşam biçiminin şekillenmesi ile ilgili sorulan "neden" sorusunun belki de en isabetli cevaplarından biri De Beauvior, tarafindan verilmiştir. O, kadını tanımlarken, aynı zamanda toplumun bilinçaltında şekillenen ve kadına biçilen kimliğin ve kadının işlevinin portresini çizer:

"Kadın, en ustalıklı aygıtların parçalara bölmekte ya da çoğaltmakta güçsüz kaldĭ̆l, zaman denen şeyin direnişini etinde duyar: $O$ bu zamanı ilkin ayın dönüş hızına bağlı olarak hisseder, yıllar bu eti önce olgunlaştırır, sonra bozar. Günlük yaşamında, mutfak ona sabrı ve edilgenliği öğretir; tam bir simya bilimidir mutfak işi; ateşin, suyun keyfine uymak, "şekerin erimesini beklemek" mayanın tutmasını, çamaşırın kurumasını, meyvelerin olgunlaşmasını beklemek gerekir. Ev işleri hemen hemen teknik bir çalışmadır; yalnız, kadının mekânik nedenselliğin yasalarına inanmasına izin verilmeyecek kadar tek düzeli ve ilkeldirler. Ayrica bu alanda bile nesnelerin kendilerine göre bir takım hevesleri vardır; bazı kumaşlar yıkamaya "gelir" bazıları "gelmez" kimi lekeler kolay çıkar, kimisi çıkmaz, kimi eşyalar durdukları yerde kırılır, toz dediğinse sanki yerden biter kadının düşünce biçimi, hala, toprağın büyülü güçlerine tapan tarımsal uygarlıklarınki gibidir." 25

$\mathrm{Bu}$ cümleden de anlaşılacağı üzere, hayata katılımları biyolojilerinin gereği olarak sadece çocuk doğurma ve çocuklarını büyütme olarak şekillenmiştir. Görev olarak algilanan bu durum bir emek olarak görülmemekte ve biyolojilerinin emeklerini gölgede bıraktığı bir durum ortaya çıkmaktadır. ${ }^{26}$

Tarih onları ataerkilliğin somurtkan yüzüne, toplum onları sınırlara, "dinin yanlış yorumu" onları kadere mahkûm etmeye çalışır. Anne-babadan, erkek kardeşten, yoksulluktan, şiddetten vs. hayatın en ürkütücü yüzünden nasiplenirler. Bütün bu olanlar toplumun kendilerine biçtiği ve iktidarların devamının sağlanması için tarih boyunca kadın bedeni üzerinde yapılan değerlendirmelerin neticesi ile alakalı olmaktadir.

Şiddete maruz kalma ve bunu cinsiyetinden dolayı benimseme, cinsiyetinden dolayı okula gönderilmeme, evlilik gibi hayati konularda fikirlerinin sorulmamas1, yoksulluktan dolayı en fazla zorluğu onların çekmesi hayatlarının özetidir.

\footnotetext{
${ }^{19}$ Millet, Cinsel Politika , 65; Firedrich Engels, Ailenin Özel Mülkiyetin ve Devletin Kökenleri, Trc. Hasan İlhan, 1. Bs.(Ankara; Alter yayınları, 2010), 68. ; Marks ,Angels, Lenin, Marksizm Kadın ve Aile, Trc. Öner Ünalan, (İstanbul; Evrensel Basım Yayın, 2014), 17.; Silvia Federici, Calıban ve Cadl, Kadınlar Beden ve Ilksel Birikim,Trc. Öznur Karakaş, 2. Bs.(İstanbul; Otonom yayınları,2014), 126.; Sheila Rowbotham, Kadının Gizlenmiş Tarihi, Trc. Nilgün Şarman, 1. Bs.(İstanbul; Payel yayınları, 2011), 20.; V.İ.Lenin, Kadınların Kurtuluşu, Trc. Ertuğrul Yemenoğlu, 1. Bs.(İstanbul; Akademi yayınlar1, 2010), 33 .

${ }_{20}$ Althusser, Devletin Ideolojik Aygltlarl, 53; Fevziye Say1lan (Der.), Toplumsal Cinsiyet ve Eğitim, 1. Bs.(Ankara; Dipnot yayınları, 2012), 21-35.

${ }^{21}$ Millet, Cinsel Politika, 71.

${ }^{22}$ Millet, Cinsel Politika 83.

${ }^{23}$ Millet, Cinsel Politika, 77.; 243.

24 Judith Butler, Cinsiyet Belası Feminizmin ve Kimliğin Altüst Edilmesi, Trc. Başak Ertür, 2. Bs. (İstanbul; Metis yayınları, 2005), 45.; Zeynep Direk (der.), Cinsiyetli Olmak Sosyal Bilimlere Feminist Bakışlar, 77.

${ }^{25}$ Simone De Beauvior, Kadın “İkinci Cins” Bă̆ımsızlı̆̆a Doğru, Trc. Bertan Onaran, 7. Bs.(İstanbul; Payel yayınları, 1993), 9.

${ }^{26}$ Maria Mies, Veronika Bennholdt- Thomsen, Cloudia Von Werlhof, Son Sömürge: Kadınlar, 104.
} 
Konuşmalarında kendilerine dair anlayışları hep baskın toplumsal cinsiyet kültürünün kendilerine yüklediği anlam ve beklentiler üzerinden gerçekleşmektedir. Kocası tarafından altı çocuğuyla terkedilen Meziyet hanım:

"E ma o bizi bıraxté gitti, gerek bende bıraxayım. Valla sebehten akşama kadar çocığımın rızkını kazanmax için çırpıniyam. Hani nasıl olur ana yüreği buna dayanmaz ki, gerek kadın daha sabırlé ola, Allah böyle yaratmış böyle söylemiş." "Babam dedi ki evlilitx bir defadır, bu evden gelinlikle çıxarsin kefenle gelirsin, hani ben boşanabilirem, zaten ayıptır bizde, kadın nasıl boşané ben Allah 'tan korxiyam”.

Bir diğer çarpıcı ifade ise Atiye Hanım'ın kullandığı; "Hané biz kadınıx, ne yapabilirıx." $\mathrm{Bu}$ ifadeler, kadınların hayatını belirlerken duygu dünyalarının oluşmasında hangi değerlerin ön plana çıktığının birer göstergesidir. Kendilerini tanımlarken, görevlerini hatırlarken, yaşantılarını ve deneyimlerini dillendirirken kullandıkları dilsel repertuarda bu değerleri görmek mümkündür. Bu dilin sözlüğü erkeklerin kullandığından çok farklıdır. Özellikle "annelik", "evin kadını", "kısmet", "kader", "korku", "Allah korkusu", "anne-baba korkusu”, "endișe”, "çaresizlik", "dayak", "dayak cennetten çıkma", "kızını dövmeyen dizini döver", "günah", "ayıp" vb. ifadelerinin bol olması, kadınların yaşamlarında neleri daha önemli bulduklarına işaret etmektedir. Bir kadının konuşmalarında "kendine güven" ifadesi, nadiren yer alır. Buna göre kadınların kendine güven duyma, kendini geliştirme, kendini güçlü hissetme, değerli bulma gibi sözcükleri kullanmaktan kaçındıklarını_söylemem mümkündür. Kadınlar hayatlarının her noktasında, uysal, sessiz, terbiyeli, sadık, mütevazı bir varlık olmanın kadınlara yakıştığını öğrenirler. Hayatları boyunca öğrendikleri ve toplum tarafından benimsetilen kendilerine dair hususlar hep başka bireylere göre belirlenmektedir. Kadınlar başkaları için var olan kişilerdir. Kendileri adeta yoktur; öncelik ailelerine çocuklarına ve anne babalarına aittir. Kendinden vazgeçip anne, eş ve evlat olmanın sorumluluğuyla "diğerleri için var olan" kişi haline gelir. Bir kadının kendini değerli biri olarak görmesi onun kibirli bir varlık olarak değerlendirilmesine yol açacaktır. Çoğu zaman bu kadınlar ancak toplum tarafından kabul gören bir evlilik yapıp istenilen sayıda çocuk yaptığında bir değer kazanır. Bu kadınların yaşamında en az bahsedilen şey başarılı olmaktır. Bașarılı olma göstergesi ise evliliğinin iyi gitmesidir. $^{27}$

$\mathrm{Bu}$ mahalledeki kadınlar kendilerini konumlandırırken, erkeklerden bir adım geride olmayı çocuk yaşta öğrenmişlerdir. ${ }^{28}$ Yemeğin en iyisi erkeğe gider. Erkekler yedikten sonra sofraya oturulur. Erkek çocuğu okutulur. Karar verirken erkeğin kararı alınır, kadına düşüncesi pek sorulup danışılmaz. Hayata daha ilk adımın atıldığı çocukluk evresinde bu iki cinse ait farklı yaklaşımlar hayatlarının daha sonraki kısımlarını da ciddi anlamda etkilemekte ve iki farklı kişiliği oluşturmaktadır. Kendini ezik ve eksik hisseden kadın, efendi ve mükemmel pozisyonunda olan ise erkektir. Buradaki tanımlamaların elbette istisnası olmakla birlikte genel çerçevenin bu olduğunu söylemem mümkündür

Portresini çıkarmaya çalıştığımız bu kadınların hayatlarını derinden etkileyen temel sorunlardan bir tanesi de elbette ki yoksulluktur. Yoksulluğu yaşama biçimlerini yine kendi ifadelerinde aktarmaya başlamadan önce yoksulluk ve yoksulluğun nedenleri üzerinde kısaca durmaya çalışacağım.

\footnotetext{
${ }^{27}$ Yasemin İnceoğlu, Altan Kar, Kadın ve Bedeni, 1. Bs. (İstanbul; Ayrıntı yayınları, 2010), 45-46.

${ }^{28}$ Horney, Kadının Ruhsal Yapısı, 54-55.
} 


\section{Yoksulluk ve Yoksulluğun Oluşturduğu Kadın İnancı}

Yoksulluk kavramı, sosyal bilimlerdeki diğer bütün ara kavramlar gibi sorunlu bir kavramdır ve sosyolojik düşünme tarihine bakıldığında, genellikle dolaylı ve ikinci dereceden bir ilgilenme söz konusudur. Bu genellemenin dişında kalan Simmel'in değerlendirmeleridir. $\mathrm{O}$, toplumsal bir bakış açısından, bireyin toplumsal çevrenin bir ürünü olduğunu ve yoksulun, yoksulluk durumunun kendisi dışında bulunan insanlara moral yükümlülükleri getirdiğini, toplumsal denklemin bozulmasından dolayı daha fazla hak talep isteğini meşru kıldığını ifade etmektedir. Simmel'e göre, yoksulluk verili bir durum olduğundan değil, vargılarına bakıldığında, yani bir sonuç olarak sosyolojik bir anlam kazanır. Bu sebeple yoksulluk sadece maddi bir sefalet olarak değerlendirilmemelidir. Yoksulluğun bu biçimde anlaşılması, yoksulluğun varoluşuna ve algılanmasına ilişkin özelliklerinde kaybolmasına yol açabilir. ${ }^{29}$

Hobsbawn, yoksulluğu üç kısımda değerlendirmektedir; toplumsal yoksulluk, sefalet ve moral yoksulluk. Toplumsal yoksulluk, yoksulluğun sadece salt maddi ölçülerle değil, aynı zamanda bağımlılık, sömürü ve aşağılık hissine bağlı olarak var olduğuna dikkat çeker. Bu düzeyde yoksulluk, göreceli olarak tanımlanabilir; çünkü burada yoksulluk, maddi girdiye rağmen var olur. Sefalet ise, verili bir toplumda minimal yaşama standartlarının altında bulunma ve böylece başkalarının yardımına bağımlı kalma durumu olarak nitelenebilir. Moral yoksulluk, toplumsal yoksulluk ve sefaletin bir sonucu olarak var olur ve "toplumun ya da onun alt guruplarının ve kurumlarının değer sisteminde yoksulluğun yerini tanımlamaktadır.",30

Sanayi toplumlarında yoksulluğun kalıcılığı ile ilgili üç genel açıklama mevcuttur. İlki, bir yoksulluk alt kültürünün, tarihte yoksullukla ilgili geleneksel tepki biçimi olarak ortaya çıkmış değerleri yeniden üreterek yoksulluğun devamının sağlandığ1 görüşüdür. $\mathrm{Bu}$ tepki biçimi, işçi sınıfının ve öteki bağımlı gurupların toplumsal yoksunluklar karşısındaki kaderciliğini, tevekkülünü, boyun eğişini barındırır. Yoksulluğun yaygınlığına ve kalıcılığına neden olan şeyin, aslında bir dizi konumsal kısıtlama olduğu fikrine de yoksulluk kültürü tezinin eleştirilmesi neticesinde ulaşıldı. Yoksullar, kötü meskenleri, düşük geliri ve yetersiz eğitimi içeren çevre koşulları tarafindan kısıtlanırlar. Her iki bakış açısına da karşı çıkan üçüncü görüş ise bu bakış açısının yoksulluğun kökenlerini değil sürekliliğini dikkate aldığını iddia eder. Buna göre yoksulluk, daha geniş bir eşitsizlik çözümlemesinde, yani bir toplumsal tabakalaşma yorumu çerçevesinde anlaşılabilir ancak. ${ }^{31} \mathrm{Bu}$ toplumsal tabakalaşma sistem tarafindan adeta desteklenmekte ve yoksulluğun devamını sağlamaktadır. ${ }^{32}$ Bunların nedenlerine kısaca değinmekte yarar vardır.

\subsection{Yoksulluğun Nedenleri}

Yoksulluğu, daha çok kişisel özelliklerle ilişkilendiren (sorumluluk, disiplin anlayışı vb.) ve yoksulları "yoksulluğun hem kurbanı ve hem de nedeni" olarak gören yaklaşımla, yoksulluğu yoksulların dışında, başta ekonomi politikaları olmak üzere, düşük ücretler, yetersiz eğitim, istihdam olanakları ve ayrımcılık gibi yoksulların kendi

\footnotetext{
${ }^{29}$ Georg Simmel, Bireysellik ve Kültür, Trc. Tuncay Birkan, 1. Bs.(İstanbul; Metis yayınları, 2009), 156178.

30 Ahmet Çiğdem, "Yoksulluk ve Dinsellik" Yoksulluk Halleri, edt. Necmi Erdoğan, 2.Bs. (İstanbul; İletişim yayınları, 2011), 205-206.

${ }^{31}$ Bryne, Turner, Eşitlik, Trc. Bahadır Sina Şener 2.Bs.(Ankara; Dost yayınları, 2007), 71.

${ }^{32}$ Bkz. Zafer Yılmaz, Yoksullarl Ne Yapmalı?, 1. Bs.(Ankara; Dipnot yayınları, 2012), 108-138.
} 
denetimleri dışındaki "yapısal” etmenlere ve bütünüyle sosyoekonomik sistemle ilişkilendirilen yaklaşım olarak iki başlık altında değerlendirilebilir. ${ }^{33}$

Büyüme, gelir dağılımı ve yoksulluk, ${ }^{34}$ demografik unsurlar: nüfus baskısı, hane halk1 özellikleri ve göç ve özellikle eğitim durumu ${ }^{35}$ başta kırdan kente olmak üzere değişik yerleşim yerleri arasındaki göçler yoksulluğu tetiklemekte veya derinleştirmektedir. ${ }^{36}$ ayrıca yoksulluğun nedenleri arasında da işgücü piyasalarından kaynaklanan nedenler ön planda tutulmaktadır. Bir gözlemciye göre, istihdam olanaklarının yetersizliği kentsel yoksulluğun önde gelen tek nedenidir."37

Üretimde ve işgücü piyasalarında yeniden yapılanma, istihdam ve işsizlik de bu başlık altında değerlendirilebilir. ${ }^{38}$ Ayrıca dışsal etmenler olarak, kişilerin ve hane halklarının yaşamlarında karşılaştıkları ve şok olarak nitelendirilebilecek durumlar, ${ }^{39}$ özellikle ırk, milliyet ve toplumsal cinsiyet gibi nedenlerden kaynaklanan ayırımcılığın bazı ülkelerde önemli boyutlara ulaştığı ve ciddi bir yoksulluk nedeni oluşturduğu görülmektedir. ${ }^{40}$ İnsanların yaşadıkları fiziksel çevre de yoksullukla yakından ilişkilidir. Ülke içinde kimi yerleşim yerleri ve daha geniş anlamda belirli bölgeler, yukarıda belirlediğimiz yoksulluk nedenlerinden bir kaçını birden barındırdıkları için yoksulluğun özellikle yoğun olduğu yerleri oluşturmaktadır. ${ }^{41}$

\subsection{Yoksul Mekânların Yoksul Kadınları}

Anlatılan yoksulluğun, bu yoksulluğu yaşayan bütün bireyleri etkilemekle birlikte birinci dereceden bundan etkilenen bireyin kadın olduğunu söylemek mümkündür. Gününün tamamını neredeyse evde geçiren kadınları etkileyen yoksulluk, "kadın yoksulluğu ve yoksulluğun kadınlaşması" kavramını beraberinde getirmektedir. Her kadından dinlediğim hayatlarına dair hikayelerde, yoksulluğu aileleri içinde büyük oranda kendileri göğüslemeye çalışmakta ve diğerlerine oranla daha ağır şekilde tecrübe etmektedirler. Görüşme yaptığım kadınların birçoğunun kocası ya çalışmamakta, ya çalışmak için şehir dışında bulunmakta ya da işlemiş olduğu suçtan dolayı hapiste yatmaktadır. Elbette eşini ve çocuklarını bırakıp giden eşlerin varlığını da unutmamak gerekir.

Ayşegül hanım:

"xocam, kocam çalışi güvenlik olarak.aama aldı̆̆ parayi kendine harci. ayda bana sadece ikiyüz lira veri ben o parayla evi geçindirmeye çalışiyam. kendıme mewlıdlere gidiyem arbane çalyyam. pazara gidiyem. en ucuz sebze hangisi ise oni aliyam. bir kilo patates aliyam üç yemek yapiyam. çocıxlarıma hama de ben baxiyam. hane ne yapabılırem başka."

Yine Fatih Paşa Aile Destek Evinde çalışan Aliye hanım:

"sılho beni ve çocıxlarımı bıraxti. başka bir karıya gitti. ben ev temizlıxlarına gittım. komşumuzun çöpünden ekmek topladım çocıxlarım için. kızılaya gididım yemăg getıridım. kur'an xocam makarna yemağtan o yemaxlari artıx görmax istemidım. şimdi

\footnotetext{
${ }^{33}$ Fikret Şenses, Küreselleşmenin Öteki Yüzü Yoksulluk, 2. Bs. (İstanbul; İletişim yayınları, 2006), 146.

${ }^{34}$ Şenses, Küreselleşmenin Öteki Yüzü, 149.

35 Şenses, Küreselleşmenin Öteki Yüzü Yoksulluk, 160.

36 Şenses, Küreselleşmenin Öteki Yüzü Yoksulluk, 161.

37 Şenses, Küreselleşmenin Öteki Yüzü Yoksulluk, 164.

38 Şenses, Küreselleşmenin Öteki Yüzü Yoksulluk, 166-167.

${ }^{39}$ Şenses, Küreselleşmenin Öteki Yüzü Yoksulluk, 171.

40 Şenses, Küreselleşmenin Öteki Yüzü Yoksulluk,173.

${ }^{41}$ Şenses, Küreselleşmenin Öteki Yüzü Yoksulluk, 179.
} 
burada çalışiyam. xocaların verdiği para ile evimi geçındırıyem. yüzelli lira aliyam. iki yüz lira olsa daha iyi geçınacağam. abemın pastaxanesi var, babamın meeşi var ama hane kim insana yardım edi. çocıxlarıma baxmam gerekır. allah baxi onlara ben baxiyam."

Eşi tarafından terk edilen Hayriye hanım ise yoksulluğunu anlatırken dört kızıyla birlikte yaşamanın zorluklarını dile getirdi. aileyi geçindirmek için çalışmak zorunda olduğunu ama çalışırken dul olması nedeniyle yaşadığı tacizleri dile getiriyordu:

"ben çalışmax zorındayam. bu gördığın eve ikiyüz elli kira veriyem. klzların büyük olmiş onları evde biraxınca korxiyam. bu mahalle pislıx doli. her yerde çalışiyam. önceleri bir lokentede çalışidım. usta başi beni taciz etti. ha ne diyabılırem bağırsam herkes beni orıspi bilecă̆. o erkektır onın başi diktır. ben kadınam ne yapabılıram."

Anlatımlar bu şekilde uzayıp gitmektedir. Yoksulluğun her anlamda bu kadınları etkilediğini söylemek gerekir. Kadın olmanın dezavantajlarını yaşayan bu kadınlar, toplumsal cinsiyetin kendilerine yüklediği ağır yükün altında ezilmektedirler. kadın olmanın, eksik olmakla ilintilendirildiği bir bakış açısının hayatlarını her alanda yaşanmaz kıldığı gibi, yoksulluğun en ağır halini de yaşamalarını beraberinde getirmektedir. Bir yandan yoksulluğu en ağır şekilde yaşarken diğer taraftan toplum ve ailenin diğer fertleri tarafından desteklenmeyen, genellikle düşük iş kalitesinin olduğu mekânlarda vasıfsız eleman olarak çalışmaları onları oldukça zorlamaktadır.

Yoksulluğun kadınlaşması, toplumsal cinsiyet eşitsizliklerine, neoliberal yeniden yapılanmanın toplumsal cinsiyete göre farklılaşan etkilerine, emeğin enformalleşmesine ve kadınlaşmasına, göç yoluyla akrabalığa dayanan ağların aşınması gibi etkilere bağlanmıştır. Bunlarla birlikte; kadının gittikçe artan hane reisliği olgusu da başat etkenlerdendir. Özellikle çalıştı̆̆ım mekânlarda kocaları tarafından terk edilen kadınların evlerini geçindirmede birinci dereceden sorumluluk aldığını yukarıda kendileri de dile getirmiştir. $\mathrm{Bu}$ olgu "kadınların hane reisi olduğu hanelerin yoksulluğunun kadınlaşması, yoksulluğun kadınlaşmasının aynı anlamlı başka bir ifadesidir" diyecek kadar ileri gitmiştir. Dolayısıyla sıklıkla yalnız anneler, kadın reisli hanelerin en büyük gurubu olduğu için ve yoksulluklarının yalnızca kendilerini değil çocuklarını da etkilediği düşünüldüğü için, bazı çevrelerde, "yalnız annelik kültürü" nün, "yeni yoksulluk paradigması" olarak tanımlanması sürpriz değildir. ${ }^{42}$

Yoksullaşmada kadının medeni durumu da önem kazanmaktadır. (yukarıda anlatımlarına yer verdiğim Hayriye hanımın dul olarak karşılaştığı zorluklara kısmen değindim.) boşanmış, dul ve yaşlı yoksul kadınlar için yardımlar daha fazla önem taşımakta ve yoksulluğu kadınlaştıran nedenlerin başında gelmektedir. Yoksul kadınların ayrıldıkları eşlerinin ya da ölen kocalarının enformel işlerde çalışmış olması ve dolayısıyla düzenli bir aile gelirlerinin olmaması yoksulluğun en önemli sebeplerinden biridir. Özünde ülkemizde yoksulluk ve enformelleşmenin birbirini beslemesi, yoksulluğun hem kadınlaşmasına, hem de kadınları yardıma yönelterek yardım alanlar içinde kadınların ezici bir çoğunlukla artmasına yol açmakta, diğer bir deyişle yardımları kadınlaştırmaktadır. Yoksul kadınlar, öncelikle aile ve akrabalarının kendilerine sahip çıkmaları beklentisi içine girmekte, bunun olmaması durumunda ise, kendisi ya da çocukları, çalışma imkânı aramaktadırlar. kadınlar, çalışmaları durumunda ise eğitim seviyelerinin düşük olması ve iş tecrübelerinin yeterli olmaması gibi

\footnotetext{
42 Sylvia Chant, "Kadın Hane Reisliği ve Yoksulluğun Kadınlaşması: Olgular, Kurgular ve Gelecek Stratejileri”, Yoksulluk ve Kadın, der. Abdullah Topçuoğlu 1. Bs.(İstanbul; Ayrıntı yayınları, 2014), 3536.
} 
nedenlerle, enformel sektörde ya da marjinal sektörlerde iş bulabilmektedirler. ${ }^{43}$ Nitekim burada da evini geçindirmeye çalışan kadınların neredeyse hepsinin, düşük ücretli düşük standartlı işlerde çalıştığını yukarıdaki örneklerle değinmeye çalıştım.

Yukarıda yoksulluğa dair teorik olarak ifade edilen bu hususların her birisini kat be kat aşan pratiklerin bu mekânlarda yaşandığına şahit oldum. Hasırlı mahallesinden Zümrüt hanımın anlatımları yoksulluğun boyutlarını ifade etmede başka da bir izaha ihtiyaç bırakmayacak derecede açıklayıcıdır:

"Xocam Kur'an fakirlikten yorlldım. yillardır o mehledeyıx. Evimi görsen haşa senden bağlasan köpeği içinde durmaz. burada çalışiyam. ancak kiraya ve erzağa veriyem. Bir gün doğru dürüst yemek yesek ü̧̧ gün yemek yiyemiylx. Kocam çalışmi. dokız nüfusa ben baxiyam. Yıllardır çalışiyam. Milletın işini yapiyam. Şimdi kocam çalışmadıği için evımıze ataş girmiş. her gün kavga ediylx. iş yox diyi. niye Allah beni görmi. vallah ben dindaram tövbe etmişem, şéxım var. Iyi kalpliyem bu halımla fakır fukaranın işine koştırıyam. inancın olsun, o kadar kizmışam ki iki gündür iki rekaat namaz kılmadım. Valla valla evimde hala buzdolabi yoxtır. Yazın gidiyem komuşilardan buz getiriyem, yemek yapiyam iki günde bozlli"

Yoksulluk sahneleri anlatılırken her manzara bir diğerini aratmaktadır. Yoksulluk, göç, şiddet, istismar, mağduriyetlerin her çeşidinin yaşandığı bu mekânlara daha yakından bakıldığında düşünülenleri aşan bir düzeyde olduğuna şahitlik ettim. Çalışmam nedeniyle mahallelere girerken gördüğüm evlerin manzaraları anlatımların çok ötesindedir. Özellikle evlerin içine girmeye başladığımda her bir evin kendisine has bir yoksulluk hikâyesi ile karşılaştım. Dışarıdan yıkık döküklügü görülen evlerin, içlerine girildiğinde, hayatlarına dokunulduğunda, görülen manzaralar aslında hayatlarının sadece panoramik bir görüntüsünden ibaretti.

Yoksulluğun kesintisiz ve en yoğun haliyle hissedildiği mekân olan evde yaşamlarının çok büyük kısmını geçirenler kadınlardır. Bu nedenle yoksulluğun en derin mekânsal hissini de onlar yaşarlar. Öyle ki, ev yoksulluklarının mahkûmiyet alanına dönüşür. $\mathrm{Bu}$ mahkûmiyetin sürdüğü ev, çoğunlukla fenni inşa edilmediğinden sağlıklı bir mekân da değildir. Bunun sonucunda, hane bireyleri bir türlü hastalıktan kurtulamazlar, ama kadınlar ve çocuklar yaşamlarını daha çok evde geçirdiklerinden, onların hastalıkları da daha çok mekân kaynaklıdır. ${ }^{44}$

Yoksulluk ve kadın ilişkisinde "hane" kadının toplumsal cinsiyet rolleriyle eklemlenmiş ev içi rollerin icra mekânıdır. Doğrudan "mekân" eksenli düşünüldüğünde, neredeyse vaktinin tamamını evde geçirenin kadın olduğu, yoksulun evinin neredeyse kadının mahkûmiyet alanı haline dönüştüğünü söylemek yanlış olmaz. yoksullukta kadının hane ile ilişkisinde hanenin mahkûmiyet alanına dönüşmesinin bir takım nedenleri bulunmaktadır. Bunlar: evde kalanların bakımı (çocuk, yaşlı, hasta) özellikle, işlevsel olmayan hane şartları (evdeki az sayıda odanın birden fazla işlev görmesi sebebiyle sabah akşam yeniden düzenlenmesi, evde kullanılan inşaat malzemelerinin niteliği rutubet gibi konumsal sorunlar vb.) ve yoksul kadının "ev ekonomisi"ni gözetme eğilimi ile bazı araçlara kendi bedenini ikame etme sürecinde gerçekleşen ve bitip tükenmeyen ev işleri, dışarıdaki hayat karşısında kendisini donanımsız ve yetersiz hissetmesi ile ulaşım bedelleri gibi gerekçeler olmaktadır. $\mathrm{Bu}$ durumda kadın, yoksulluğun kesintisiz ve en yoğun hali ile tecrübe edildiği yer olan hane ile dolaylı

\footnotetext{
${ }^{43}$ Songül Sallan Gül, Büşra Bayram, "Bir Sosyal Yardım Olarak Dul Kadın Maaşı ve Ataerkil Pazarlığın Koşulları; Elazığ Örneği, Akademia Sosyal Bilimler Dergisi, 1/4, (2018): 42

44 Ersan Ocak, "Yoksulun Evi", Yoksulluk Halleri, Editör Necmi Erdoğan, 2. Bs.(İstanbul; İletişim yayınları, 2011), 171.
} 
olarak da yoksullukla sürekli yüzleşmek durumunda kalır. Yoksulluğunu evin içine kapanarak örtmeye çalışır. Yoksulun evi, yoksulluğun sıkıntılarının biriktirildiği bir kabuğa dönüşür. Bu kabuğun altındaki yaranın derinliği ve bu yaranın yarattığ1 sıkıntılar dışarıda durumu daha iyi olanlar tarafından görülmez, duyulmaz, bilinmez. ${ }^{45}$ $\mathrm{Bu}$ durum görüştüğümüz kadınlar tarafından da birçok defa dile getirildi: "valla xocam köpeği bağlasan burada durmi ama ne yapax" diyen Feride hanımın evi, sokaktan geçerken harabe olduğu her haliyle belliydi. Belli belirsiz duran kapısına, dikkatli bakılmadığında görünmez gibiydi.

Buradaki yoksulluğu görmek için, evlerden sadece birinin tasviri yeterlidir. Küçük ve altı çürümüş demir kapı açıldığında, dar ve küçük bir giriş, sokak kapısına bitişik, tül perdeyle kapatılmaya çalışılan, kanalizasyon giderinin kötülüğü yüzünden kokan, aynı zamanda kışın avlu soğuk olduğu için banyo olarak da kullanılan tuvalet; tuvaletin hemen bitişiğinde derme çatma bir mutfak tezgâhı, dağınık birkaç kap kacak, odanın kapısı ve tezgâh arasına sıkıştırılmış çoğu zaman bozuk olan bir buzdolabı bulunuyordu.

Aynı şekilde üç çocuklu Feride hanımın tek yaşam alanı olan bir odaya bakıldığında, içeriye sinmiş rutubet kokusu, yerde küçücük eski bir halı, bir kaç minder ve yastık vardı. Evde çocukların tek eğlencesi olan televizyon, bir yanıyla da bu aileler için büyük bir sorun alanı oluşturmaktayd. Feride hanımın ifadesiyle; "xocam bu reklamlar aslında heç iyi bişi degıl. ha bax bu sıléman göri isti, ben alamiyam, anne diyi çikolata sucuk hani ben alabiliyem, alamiyam" şeklindeki yakınmaları, reklamların bu yoksul insanların hayatında nasıl yaralar açtığını da göstermektedir.

Bütün çıplaklığıyla ve bütün yoksunluğuyla yaşam mücadelesi veren bir başka kadın aliye hanımdır. Küçücük ve dar bir kapıdan evine geçildiğinde; küçük bir giriş, karşıda küçük bir kiler-hem banyo hem de mutfak olarak kullanılmaktadır- tek gözlü bir oda, içerde sadece bir televizyon, bir kanepenin olduğu bu evde yaşamaya çalışan aliye hanım, kocası tarafından beş çocuğu ile terk edilmiş bir kadındır. Çaresizliğini şu cümlelerle ifade etmiştir: :

“xocam kur'an kur'an ben bu eve geldiğimde, ne bir kapısi ne bir penceresi ne hiçbir şeyi yoxti. kapıya soğuk girmesin diye bir kilim asmiştım, pencereleride laylonla kapatmağa çalışidım. sonra sonra bu hale getirdım."

Evini bu duruma getirmeye çalıştığını ifade ederken şükür kavramını kullanmayı da ihmal etmiyordu.

Konuştuğum her kadının mutlaka bir hastalığı vardı. Bir çoğunda kadın hastalı̆̆ olmakla birlikte, böbrek rahatsızlıkları, soluk benizlilikleri yoksulluğun bedenleriyle buluştuğunun ifadesiydi. Sağlıksız ev ortamı, yeteri kadar besin alamama, kısaca yoksulluk ile bağdaştırılabilecek sağlık sorunlarının mevcudiyeti hemen göz çarpmaktadır.

Toplumsal sistemin işleyişi ve devamı kadınların sağlıklı olması ile yakından ilişkilidir. Kadın, özel ve kamusal alandaki görevlerini ancak sağlıklı olabildiği sürece yerine getirebilir. diğer bir ifade ile toplumdaki kadın nüfusunun sağlıklı olması, kadınların toplumsal yaşamın bütün alanlarına üretken olarak katılmasının ön şartlarından biridir. Ancak özellikle ataerkilliğin neden olduğu sosyal ve ekonomik eşitsizlikler, sağlık alanında, erkekler ile ikincil statüye sahip kadınları farklı biçimde etkilemektedir. ${ }^{46}$

\footnotetext{
${ }^{45}$ Ocak, "Yoksulun Evi", 171.

${ }^{46}$ Chant, "Kadın Hane Reisliği ve Yoksulluğun Kadınlaşması", 22.
} 
Kadınların günlük işleri olan yemek yapmak, bulaşık ve çamaşır yıkamak, ütü yapmak, evi temizlemek ve çocuklara bakmak gibi ev içinde gerçekleştirdikleri bu işler onların sağlığı ile yakından ilgilidir. Örneğin dikkat edilmeden yanlış pozisyonlarda yapılan ev işleri, fiziksel rahatsızlıklara sebebiyet verebilmektedir. Diğer yandan çalışan kadınlar, hem dışarıda hem de evde yoğun emek harcadıkları için çift yönlü bir mücadele içinde fiziksel ve psikolojik olarak yıpranmaktadır. Bununla birlikte aile içi şiddet, sosyal ve ekonomik bağımlılık, bölgesel kalkınma eşitsizlikleri ve yoksulluk kadın sağlığını olumsuz etkileyen nedenlerdir. Toplumsal cinsiyet eşitsizliğin sağlık alanında da yaşandığına dair yapılan birçok çalışmada ise özellikle yetersiz beslenen ve kötü koşullarda yaşamını sürdüren yoksul kadınların tüm kadın nüfusu içinde daha dezavantajlı olduğu kabul görmektedir. ${ }^{47}$

Yaşadıkları bütün bu zorluklarla birlikte bu kadınların hayata tutunmaları ve yaşamlarının devamını sağlayan şeyin ne olduğuna dair zihnimde oluşan sorulara yine onların sözlerinden yola çıkarak bir anlam bulmaya çalıştım. Onların bu tahammüllerinin büyük oranda dini söylem üzerinden şekillendiğini aşağıdaki başlık altında verdiğim ifadeler en net haliyle kendini göstermektedir.

\section{Yoksulluk ve Yokluğa Karşı Bir Sığınak Olarak Geliştirilen Dini Argümanlar}

Toplumsal bir varlık olan insan, birlikte yaşamanın zorunluluğu sebebiyle başlangıçtan bugüne belli sosyal, siyasal ve kültürel kurallarla yaşamını devam ettirmiştir. Bu kuralların en temel belirleyicilerinden birisi de hiç şüphesiz din olmuştur. ${ }^{48}$ Tarihin başlangıcından bugüne dinin, merkezi bir rol oynadığ 1 bireysel ${ }^{49}$ ve toplumsal olanı biçimlendirdiği tartışmasız bir gerçekliktir. ${ }^{50}$ Dini literatürde, gönderilen peygamberlerin sayısı yüzbinlerle ifade edilmiştir. Bu da dinlerin, toplumların yaşamlarında oynadığ role işaret etmektedir. Insan hayatında merkezi bir rol oynayan dinin bu kadınların hayatındaki işlevini ortaya koymanın en iyi yolu kendi yaşamlarından kesitler ve söylemleri üzerinden ortaya koymaktır.

Fatih paşa mahallesinde Aliye hanım ve hasırlı mahallesinde Hayriye hanımın yaşadıkları mekânlar ve bu mekânların barındırdığı derin bir yoksulluk ve yokluğa rağmen kullandıkları dil, onların bütün bu zorluğa nasıl katlandıklarını bize göstermektedir. Özellikle bunlardan Hayriye hanımın hayatı tam bir trajediydi. Daha eve girer girmez, yaşanılan trajedinin ağırlığı duvarlara sinmişti sanki. Küçük bir kapı hemen -girişinde sol tarafta banyo ve mutfak olarak kullanılan küçük bir yer, hemen bitişiğinde, bir tuvalet, banyonun karşısında küçük bir oda, küçücük bir pencere, yerde yırtık bir kilim, bir televizyon ve bir buzdolabından müteşekkil bir mekânda yaşamlarını sürdürüyorlardı.

Hayriye hanımın ifadesine göre yukarıda da bir oda var ve bu oda da akli dengesini yitirmiş ablası kalıyordu. Zorla evlendirildiğini, her türlü işkenceye tabi tutulduğunu,

\footnotetext{
${ }^{47}$ Chant, "Kadın Hane Reisliği ve Yoksulluğun Kadınlaşması", 22.

48 Mircea Eliade, Dinsel Inançlar ve Düşünceler Tarihi, Trc. Ali Berktay, 3.Bs. (İstanbul; Kabalcı yayınları, 2012), 1/17-40.

49 Talal Asad, Dinin Soykütükleri, Hıristiyanlıkta ve İslamda İktidarın Nedenleri ve Disiplin, Trc. Ayet Aram Tekin 1. Bs.(İstanbul Metis yayınları, 2014), 61.; Bkz. Emile Durkheim, Intihar, Trc.Özer Ozankaya, 2. Bs.(İstanbul, Cem yayınları, 2011) 172.; Sigmund Freud, Dinin Kökenleri, Trc. Ayşe Tekşen Kapkın, 1. Bs.(İstanbul; Payel yayınları, 2002), 39.

${ }^{50}$ Emile Durkheim, Dini Hayatın İlkel Biçimleri, Trc. Fuat Aydın, 2. Bs.(Ankara; Eskiyeni yayınları, 2011), 285.

Max Weber, Din Sosyolojisi, Trc. Latif Boyacı, 1. Bs. (İstanbul; Yarın yayınları, 2012), 33.
} 
aç, susuz yaşamaya mahkûm edildiğini, bütün bu yaşanmışlıkların doğurduğu ağır sorunlar nedeniyle aile içi geçimsizlik ve şiddetin her türlüsünün yaşandığı bir hayat manzarası mevcuttu. Bu noktada esas sorulması gereken soru şu: yukarıda kısmi olarak resmedilen mekânlarda yaşamaya mahkum edilmiş bu yoksul kadınlar, hangi temel düşünceye, ya da hangi saikle yaşamlarına devam edebilmektedirler? Bu temel sorunun cevabı, çalışma alanımda kendileriyle görüştüğümüz kadınların anlatımlarında mevcuttur.

Dikkate alınması gereken bir başka husus, sözü edilen kadınların eğitimsiz olmalarıdır. Eğitim düzeyleri oldukça düşük olan kadınların çoğu ya okuma yazma bilmiyor, ya da sonradan okuma yazma kurslarında basit düzeyde bir eğitim görmüşlerdir. Üstelik eğitimsiz olmaları da önemli oranda cinsiyetleri ile alakalı bir durumdur. Zümrüt hanım, babasının kendisini okula göndermeme gerekçesini anlatırken; "xocam babam beni okula göndermedi dedi eger kızlar okula giderse köti yola düşer, sevgililerine mektup yazarlar". Hayriye hanım da okula gitmeme gerekçesini şöyle dile getiriyordu: "xocam babam erkek kardeşlerimi okula gönderdi. Onlar erkektır gidebılırler. Ailem yoksuldi bütün çocığlarıni göndermedi sadece oğlanları gönderdi babam”

Okuma yazma oranının oldukça düşük olduğu kadınların dini eğitimi de de okuldan ziyade yaşadığı mekânda ya da o mekâna yakın herhangi dini bir kurum veya tarikat evlerinde devam etmektedir. Kadınların birçoğu çocuk yaşta namaz kılmayı aileden öğrendiğini ve çocuk yaştayken örtündüklerini, şehirde doğup büyüyenler ise Kur'an okumayı mahalle arasında Kur'an okumayı bilen kadınlardan öğrendiklerini, köyde doğup büyüyen kadınlar ise köy imamının eşinden ya da kızından öğrendiklerini ifade etmişlerdir.

Geleneksel dini eğitim ve söylemin egemen olduğu mekânlarda büyüyen insanlar zorunlu olarak, edindikleri bu inanç ve söylem üzerinden hayatlarını biçimlendireceklerdir. Dolayısıyla geleneksel dini düşüncenin kadına dair geliştirdiği söylem, bu mekânlarda yaşayan kadınların hayatlarında egemendir. Bu çerçevede Gazali'nin kadına dair yaklaşım biçimi ve değerlendirmelerine bakıldığında, Müslüman kadına biçilen rol daha iyi anlaşılacak ve yoksul mekânlarda yaşayan yoksul kadınların yaşamlarında da bunların nasıl yer aldığı görülecektir. ${ }^{51}$

Genel değerlendirmelerde ilim mü'minler için en önemli ibadet şekli olarak kabul edilmiştir. Ancak uygulamada bu ilim elde etme talebi daha ziyade erkek merkezli bir eğitim tarzı olmuştur. Kadınlar, doğrudan eğitim faaliyetine katılma yerine, daha ziyade ilim elde etme yolunda erkeğine hizmet etmek biçiminde bir işlev görmüştür. ${ }^{52}$

Gazali’nin değerlendirmelerine göre: “kişi evlenince evi-derleyip düzenlemekten yemek pişirmekten, etrafı süpürmekten, yaygıları yaymaktan, kap-kacağı yıkamaktan ve diğer yaşam araçlarını sağlama zahmetinden kurtulur. Evet kişinin cinsel sorunu olmasa bile evinde tek başına kalması zordur. Çünkü ev işlerini kendisi yapmaya kalkışsa zamanlarının çoğu boşa gider, ne ilmi çalışmalara ne de ibadet yapmaya vakit bulabilir. Öyleyse dindar ve ev işlerinden anlayan bir kadın bu yolla kocasının dini hayatına yardımcı olur. Bütün bu işlerin düzen içinde yürümemesi bir sıkıntıdır, zihni meşgul eden, yaşamı çekilmez hale sokan etkenlerdir. Bundan ötürü Ebu Süfyan ed-darani şunları söylemiştir: "Dindar bir kadın dünyalık sayılmaz, o ahirete yönelmene, ahiret için çalışmana imkân hazırlar." dindar kadının, kocası için hazırlayacağı bu imkânı hem

\footnotetext{
${ }^{51}$ Gazali İhya 'u Ulum 'id Din, Trc. Sitkı Gülle, 1.Bs.(İstanbul; Huzur yayınları, 201), 2:76.

52 Pınar ilkkaracan, Müslüman Toplumlarda Kadın ve Cinsellik, 5. Bs . ( İstanbul: İletişim yayınları, 2015), 53
} 
evinin işlerini görmesi açısından hem de cinsel isteklerini karşılaması noktasından değerlendirilmelidir. ${ }^{53}$

Yukarıda ifade edilen paragrafta görüldüğü şekliyle bir dini eğitime tabi tutulan ve bu eğitim tarzının egemen olduğu bir toplumsal söylemle büyüyen kadınlarda bunun hayatlarının bütün alanlarına sirayet ettiğini görmek mümkündür. Ayşe hanım: "xoca, kocamdır Allah demiş eger benden sonra birine secde edecekseniz bu kocaniz olur, hani ben Allah'ın emrine nasıl karşı geleyim hema sen söyle". Dolayısıla bu söylem tarzı, sadece bir ifade biçimi değil, aynı zamanda bir inanç şekli olarak da hayatlarında yer edinmiştir.

Aliye hanım:

"ben bu rızka layık değilim, Allah bana veriyor. Binlerce kez şükürler olsun bu nimetleri verdi. Bir zamanlar kuru ekmek yoktu yiyelim. Annemlerden çay çaliyordum, yengem bana yardım ediyordu, anneme söylemiyordu. o yüzden şimdi yengemler çok zengindirler. Komşuların kuru ekmeklerini koyduğu bir tenekemiz vardı pencerede. Ben gözetliyordum kimse etrafta olmayınca, hemen tenekeden o kuru ekmeği alıp islatıp yiyiyordıx. Hocam insan açlıktan uyuyamıyor. Nohut kaynatıp satardım. Kızılay yemeklerini yemekten makarnadan midem bulaniyor. Ben bir şey demiyorum. Allah ve peygamberine havale ediyorum. Allahtan büyük kimse yok. Iyi ki kocam evlendi, yoksa beni çoktan öldürürdi. allah bana ihsanda bulundu ki kocam evlendi. Yine yarabbi çok şükür hamd sanadır. xocam ben çox yoxlıx çektım. Walla valla yiyecağ ekemğım yoxti. Pazar dağlldixtan sonra gididım pazara, arta kalan sebze ve meyveyi getirdim, pişirdim. Şimdi allah'a çox şükür ediyem. Burada çalışiyam. xocalar aylık bana yüz elli lira veriler. geçıniyem ama iki yüz lira olsa daha iyi geçımım olacă̆. xocam bilisen, ben hep söyliyem, benım en büyük dilegim mutfă̆l olan bir evımın olmasi, çox istiyem, içinde böyle yemek pişireyim, doya doya bulaşıx ylxıyayim şimdi bir yemax pişiriyem koxısi her tarafa yaylli, bir bulaşıx ylxiyem, her taraf bati."

Yukarıda sorduğumuz sorunun cevabını bu anlatımda görmek mümkündür. Aliye hanımın bütün bu yaşadıklarına rağmen şükür ifadesini sıklıkla kullanması, onun zihin ve duygu dünyasında dinin nedenli önemli bir yer tuttuğunu göstermektedir. Sahip olduğu dini anlayış, yaşanılan zorluklar karşısında sabretmeyi bütün olumsuzluklara rağmen katlanmak olarak anlatmakta, ${ }^{54}$ hiç bir şekilde isyan ifade eden bir değerlendirmede bulunmamaları, bu kadınların inandıkları değerlere nasıl sarıldıklarını göstermektedir. Geleneksel anlayışta mevcut olan inanışa göre, her bir kul, daha doğmadan rızkı kendisi için takdir edilmiştir ve bu takdir edilen rızkın ötesine geçme şansına sahip değildir. ${ }^{55} \mathrm{O}$ nedenle yaşadıkları yoksulluğa karşı razı olmama ifadelerini kullanmada 1srarla kaçınmaktadırlar. Zira onlara göre madem bu yoksulluk kendileri için böyle takdir edilmiş, öyleyse buna şükretmeleri gerekmektedir. Bunun dişındaki her türlü değerlendirmeyi de bir günah yaklaşımı olarak kabul etmektedirler.

Söz konusu edilen bu değerlendirmelerin en somut ifadeleri Zehra hanımın şu yaklaşımında görülmektedir:

"keşke anne bizim de mutfağımız olsa, bizde süslesek, süs eşyaları alsak”. Ben diyorum ki "klzım çok şükür, evimize haram lokma girmiyor, aç değiliz, geçimimizi să̆llyoruz.

\footnotetext{
${ }^{53}$ Gazali, Ihya'u Ulum 'id Din, 2:79.

${ }^{54}$ İmam Gazali, Ihya 'u Ulum'id Din,), 4/126-155.

55 Bkz. Ebu'l-Hasan el-Eş'ari, el-İbane an Usuli'di-Diyane, (Beyrut;Daru İbn Zeydun), 59; Ebu'lMansur el-Maturidi, Kitabu't-Tevhid, thk. Bekir Topaloğlu-Muhammed Aruşi, (Beyrut; Daru Sadır), 37. ; İmamu'l-Haremeyn el-Cüveyni, Kitabu'l-İşad ila Kavatii'l-İ'tikad, thk., Muhammed Yusuf Musa-Ali Abdulmu'min (Misır; Matbaatu'saade), 364-366; Sa'duddin Taftazani, Şerhu'l-Makasıd, thk. Abdurrahman Umayra,(Beyrut; Alemu'l-Kutub,1998),318.
} 
Dünyada bizim de kısmetimiz budur. Herkesin rızk kendisinedir". Hiçbir zaman isyan etmedim. Her zaman Allah'a hamd ve şükrettim. Eşim săg olsun, çocuklarının başında olsun, huzurum olsun, bu bana yeter. Bazen diyorum keşke, ben de bir dairede rahat bir hayat sürseydim. Zengin olmak, paranın olması güzeldir. Ama yine de Allah'a binlerce kez şükürler olsun. Kaderde ne varsa onu göriylx."

$\mathrm{Bu}$ ifadelerden de anlaşılacağı gibi buradaki kadınların ortak özelliklerinden biri de "rızık" kavramına yükledikleri anlamdır. 'Kendileri için belirlenen bir rızkın bulunduğuna ve buna şükretmeleri gerektiğine dair genel kabuldür.' Yukarıda kısaca işaret edildiği gibi, klasik metinlerimizin çoğunda buna benzer bir yaklaşım bulunmaktadır. ${ }^{56}$ Doğal olarak nesilden nesle aktarılan bu değerlendirme nihayetinde bu kadınların yaşamlarında bir inanç biçimi haline gelmiştir. Hiç şüphesiz, bu yaklaşım, dayanılması güç bu yaşam savaşında onlara büyük bir güç ve inanç vermektedir.

\section{SONUÇ}

Toplumların bir arada yaşamalarını sağlayan pek çok farklı unsurlar mevcuttur. Kendi toplumumuz özelinde bakıldığında, bir arada yaşamayı sağlayan temel etmenlerin başında dini düşünce gelmektedir. İnsanların yaşadıkları her türlü olumsuzluklara karşı kendileri için dini bir dayanak olarak görmeleri, her birimizin yaşamında gözlemlerimizle muttali olduğumuz gibi, pek çok alanda yapılmış araştırma ve bilimsel çalışmalarda da bu sonuca ulaşılmıştır. Detaylı bir şekilde çalıştı̆̆ım alanda yoksulluğun ve yokluğun her türlüsünü yaşayan kadınların en büyük dayanaklarının da gene sahip oldukları dini anlayış, kullandıkları şükür ve sabır ifadeleridir. Aynı şekilde temel İslam inançları arsında sayılan; "rızkın önceden belirlenmiş olduğu", "başa gelene karşı sabır edilmesi gerektiği", "bu dünyada katlanılan her türlü zorluğun ahirette nimetlerle mükafatlandırılacağı”" düşünceleri, yaşanılan zorluğa katlanılmasını sağlayan temel unsurların başında gelmektedir.

\footnotetext{
56 Sa'duddin Taftazani, Şerhu'l-Akaidi'n-Nesefiyye, Thk. Ahmed Hicazi es-Sika,(Kahire; Mektebetu'lKülliyati'l-Ezheriyye, 1988), 65.
} 


\section{KAYNAKÇA}

Althusser, Louis İdeoloji ve Devletin İdeolojik Aygitlarl, Trc. Alp Tümertekin, İstanbul: İthaki yayınları,2014.

Asad, Talal, Dinin Soykütükleri, Hıristiyanlıkta ve İslamda İktidarın Nedenleri ve Disiplin, Trc. Ayet Aram Tekin, İstanbul: Metis yayınları, 2014.

Baloğlu, Filiz, “Kentsel Yoksulluk: İstanbul'dan Küçük Bir Kesit,” Sosyoloji Konferansları,0/31, (2005), 231-249.

Berktay, Fatmagül, Tarihin Cinsiyeti, İstanbul; Metis yayınları, 2012.

Berktay, Fatmagül, Tek Tanrılı Dinler Karşısında Kadın, İstanbul: Metis yayınları, 2012.

Butler, Judith Cinsiyet Belası Feminizmin ve Kimliğin Altüst Edilmesi, Trc. Başak Ertür, İstanbul: Metis yayınları, 2005.

Butler, Judith, Savaş Tertibleri, Trc. Şeyda Öztürk, İstanbul: Yapı Kredi yayınları, 2009.

Chant, Sylvia, Kadın Hane Reisliği ve Yoksulluğun Kadınlaşması: Olgular, Kurgular ve Gelecek Stratejileri" Yoksulluk ve Kadın, Der. Abdullah Topçuoğlu, İstanbul: Ayrıntı yayınları, 2014.

Çiğdem, Ahmet, "Yoksulluk ve Dinsellik" Yoksulluk Halleri, Edt., Necmi Erdoğan, İstanbul: İletişim yayınları, 2011.

De Beauvoir Simone, Kadın “íkinci Cins” Bă̆ımsızlı̆̆a Doğru, Trc. Bertan Onaran, İstanbul: Payel yayınları, 1993.

De Beauvoir, Simone, Kadın İkinci Cins Genç Kızlık Çă̆ı, Trc. Bertan Onaran, İstanbul: Payel yayınları, 1993.

De Beauvoir, Simone, Kadın İkinci Cins Evlilik Çă̆l, Trc. Bertan Onaran İstanbul; Payel yayınları, 2010.

Direk, Zeynep (der.), Cinsiyetli Olmak Sosyal Bilimlere Feminist Bakışlar, İstanbul: Yapı Kredi yayınları, 2014.

Durkheim, Emile, İntihar, Trc.Özer Ozankaya, İstanbul:Cem yayınları, 2011.

Durkheim, Emile, Dini Hayatın Illkel Biçimleri, Trc. Fuat Aydın, Ankara: Eskiyeni yayınlar1, 2011.

el-Cüveyni, İmamu'l-Haremeyn Kitabu'l-İrşad ila Kavatii'l-İ'tikad, (thk.), Muhammed Yusuf Musa-Ali Abdulmu'min Misir: Matbaatu'saade.

el-Eş'ari, Ebu'l-Hasan, el-İbane an Usuli'di-Diyane, Beyrut: Daru İbn Zeydun,

Eliade, Mircea Dinsel İnançlar ve Düşünceler Tarihi, Trc. Ali Berktay, İstanbul: Kabalc1 yayınları, 2012.

el-Maturidi, Ebu'l-Mansur Kitabu't-Tevhid, thk. Bekir Topaloğlu-Muhammed Aruşi, Beyrut: Daru Sadır.

Engels, Firedrich, Ailenin Özel Mülkiyetin ve Devletin Kökenleri, Trc. Hasan İlhan (Ankara: Alter yayınları, 2010

Erbil, Pervin, Kibele'den Pandora'ya Kadının Tarihsel Yenilgisi, Ankara: Arkadaş yayınları, 2012. 
Federici, Silvia, Calıban ve Cadl, Kadınlar Beden ve İlksel Birikim, Trc. Öznur Karakaş, İstanbul: Otonom yayınları, 2014.

Freud, Sigmund, Dinin Kökenleri, Trc. Ayşe Tekşen Kapkın, İstanbul: Payel yayınları, 2002.

Freud, Sigmund, Cinsiyet Üzerine, Trc. A.Avni Öneş, İstanbul: Say yayınları,2015.

Horney, Karen, Kadının Ruhsal Yapısı, Trc. Nilgün Şarman İstanbul: Payel yayınları, 1998.

İlkkaracan, Pınar Müslüman Toplumlarda Kadın ve Cinsellik, İstanbul: İletişim yayınları, 2015.

İmam Gazali, İhya 'u Ulum 'id Din, Trc. Sıtkı Gülle, İstanbul; Huzur yayınları, 2012.

İnceoğlu, Yasemin- Kar, Altan, Kadın ve Bedeni, İstanbul: Ayrıntı yayınları, 2010.

İrigaray, Luce, Başlangıçta Kadın Vardı, Trc. İlknur Özallı-Melike Odabaş, İstanbul: Pinhan yayınları, 2014.

Keller, Evelyn Fox, Toplumsal Cinsiyet ve Bilim Üzerine Düşünceler, Trc. Ferit Burak Aydar, İstanbul: Metis yayınları, 2007.

Lefebvre, Henri, Mekânın Üretimi, Trc. Işık Ergüden, İstanbul: Sel yayınları, 2015.

Marks ,Angels, Lenin, Marksizm Kadın ve Aile, Trc. Öner Ünalan, İstanbul: Evrensel Basım Yayın, 2014.

Mies, Maria, Bennholdt -Thomsen, Veronika, Von Werlhof, Cloudia Son Sömürge: Kadınlar, Trc. Yıldız Temurtürkan, İstanbul: İletişim yayınları, 2014.

Millet, Kate, Cinsel Politika, Trc. Seçkin Selvi, İstanbul: Payel yayınları, 2011.

Özyılmaz, Havva, Karakaş, Sertaç, Karaşin, Abdulhalim, Diyarbakır'da Yoğun Göçün Getirdiği Çarpık Kentleşme Sorunları, TMMOB Afet Sempozyumu, 329-335, Ankara: Mattek Matbaacilık, 2007.

Plumwood, Val, Feminizm ve Doğaya Hükmetmek, Trc. Başak Ertür, İstanbul: Metis yayınlar1, 2004.

Rose, Jacqueline, Görme ve Cinsellik, Trc. Ayşe Deniz Temiz, İstanbul: Metis yayınları, 2009.

Rowbotham, Sheila, Kadının Gizlenmiş Tarihi, Trc. Nilgün Şarman, İstanbul: Payel yayınları, 2011.

Sallan Gül, Songül, Bayram, Büşra, "Bir Sosyal Yardım Olarak Dul Kadın Maaşı ve Ataerkil Pazarlığın Koşulları; Elazığ Örneği, Akademia Sosyal Bilimler Dergisi, $1 / 4,(2018)$

Sayar, Kemal, Olmak Cesareti, İstanbul: Timaş yayınları, 2013.

Saylan, Fevziye Sayılan, Toplumsal Cinsiyet ve Eğitim, Ankara: Dipnot yayınları, 2012.

Schick, İrvin Cemil, Bedeni, Toplumu Kainatı Yaratmak, Trc. Pelin Tünaydın İstanbul: İletişim yayınları, 2011.

Simmel, Georg, Bireysellik ve Kültür, Trc.Tuncay Birkan, İstanbul:Metis yayınları, 2009.

Stone, Merlin, Tanrılar Kadınken, Trc. Nilgün Şarman, İstanbul: Payel yayınları, 2000. 
Şenses, Fikret, Küreselleşmenin Öteki Yüzü Yoksulluk, İstanbul: İletişim

Taftazani, Sa'duddin, Şerhu'l-Makasıd, thk. Abdurrahman Umayra, Beyrut: Alemu'lKutub,1998.

Taftazani, Sa'duddin Şerhu'l-Akaidi'n-Nesefiyye, Thk. Ahmed Hicazi es-Sika, Kahire: Mektebetu'l-Külliyati'l-Ezheriyye, 1988.

Turner, Eşitlik, Trc. Bahadır Sina Şener, Ankara: Dost yayınları, 2007.

V.İ.Lenin, Kadınların Kurtuluşu, Trc. Ertuğrul Yemenoğlu, İstanbul: Akademi yayınlar1, 2010.

Weber, Max, Din Sosyolojisi, Trc. Latif Boyacı, İstanbul: Yarın yayınları, 2012.

Y1lmaz, Zafer Yoksulları Ne Yapmalı?, Ankara: Dipnot yayınları, 2012. 